\title{
The German Teacher Trainers' Self-Efficacy Beliefs
}

\author{
Veli Batdi ${ }^{1}$ \\ ${ }^{1}$ Ministry of Education, Elazı $\breve{g}$, Turkey \\ Correspondence: Veli Batdi, Ministry of Education, Elazığ, Turkey
}

Received: July 23, 2014 Accepted: August 7, 2014 Online Published: August 14, 2014

doi:10.11114/jets.v2i4.490

URL:http://dx.doi.org/10.11114/jets.v2i4.490

\begin{abstract}
In this study, the aim is to identify the interpersonal self-efficacy beliefs of German teacher trainers' in Turkey. It is a descriptive survey and the population of the study consists of German teacher trainers who have worked in the seven regions of Turkey during the 2012-2013 academic year. The sample comprises 52 German teacher trainers chosen randomly from the related population. The version of "The Teacher Interpersonal Self-efficacy Scale (TISE)" which was developed by Brouwers and Tomic (2002), translated into Turkish and whose reliability and validity were determined by Çapri and Kan (2006), was used to collect data. As a result of the study, it is understood that the level of self-efficacy beliefs, particularly of more experienced male teachers, is high.
\end{abstract}

Keywords: German teacher trainers, self-efficacy beliefs, interpersonal self-efficacy, teaching process

\section{Introduction}

\subsection{The Problem}

Self-efficacy is a concept which is mentioned in Bandura's Social Learning Theory (Guo, Piasta, Justice, \& Kaderavek, 2010, p. 1095). Self-efficacy is defined as ones' beliefs about ones' capabilities to carry out necessary activities to successfully display a performance in ones' life (Bandura, 1991, p. 1). Accordingly, self-efficacy can be understood as ones' beliefs about ones' abilities to be able to carry out some behaviors to achieve something successfully. On the other hand, Evers, Brouwers and Tomic (2002, p. 229) state that self-efficacy is related not only to ones' skills or competences but also the belief that one is able to do things in some cases. So, self-efficacy includes both ones' competences and beliefs in terms of oneself being able to operate successfully. On the other hand, self-efficacy has been stated to have a contextual characteristic rather than being a global concept, because ones' self-efficacy can be differ in different situations (Bandura, 1986; as cited in Guo, Justice, Sawyer and Tompkins, 2011, p. 962). For instance, a teacher whose self-efficacy in a science class is low, can have a high self-efficacy when it comes to teaching a language class. Under this circumstance, it can be thought that the teacher will make a greater effort in the language class, and strive to capture his/her students' attention more (Paraskeva, Bouta, \& Papagianni, 2008, p. 1086).

The concept of teacher self-efficacy has appeared in the educational context recently, and a number of studies have been conducted about teacher self-efficacy (Chan, 2008; Liaw, 2008; Kim \& Kim, 2010) and has come to be known as a characteristic that belongs to a teacher (Savran, Gencer, \& Çakıroğlu, 2007, p. 664; Milner \& Hoy, 2003, p. 264: Klassen \& Chiu, 2011, p. 115). Teacher self-efficacy is concerned with the beliefs that the teacher can affect the behaviours or academic achievement of students, particularly of poorly motivated students or those who have difficulty in learning. So, this concept expresses a teacher's wide ranging roles in class in one sense (Friedman \& Kass, 2002, p. 675). In addition, teacher behaviours in the classroom environment are related to teacher self-efficacy. A teacher's attempts to teach and the determination of his /her goals and aims are affected by the self-efficacy concept. Those teachers who have a high level of self-efficacy are more open to new ideas and more eager to use different teaching methods and techniques for the purpose of meeting their students' needs in the optimum way (Milner \& Hoy, 2003, p. 264). Self-efficacy beliefs include perceived self-efficacy with regard to future oriented judgment rather than the actual self-efficacy level. The difference between actual self-efficacy and perceived self-efficacy is important. The main reason for this is that individuals usually exaggerate their actual self-efficacy or see it as inadequate. This exaggeration or underestimation considerably affects how they initiate an action, sustain it and make an effort with regard to it because "...a competence is as well as it can be shown" (Hoy \& Spero, 2005, p. 344). So, how individuals act and struggle in a difficult situation indicates their self-efficacy level. 
A number of studies confirm that teacher self-efficacy belief has a significant positive impact on the level of motivation and performance (Bandura \& Locke, 2003; Lee, Cawthon, \& Dawson, 2013; Cho \& Shim, 2013). Bandura (1977) states that self-efficacy belief is much stronger than an individual's actual competences, and this belief affects others' motivation levels and affective states. For that reason, a teacher who is not hopeful about being successful in his/her classes will tend to put in less effort in preparation for teaching and in the teaching process (Tschannen-Moran \& Johnson, 2011, p. 751). Accordingly, a highly effective learning environment is unlikely to exist as a result. At this point, it can be stated that an increasing level of teacher satisfaction with their work will increase their motivation, and the motivated teachers will arouse intrinsic motivation in their students and enable the students to grasp the importance of learning. A teacher being satisfied with his/her profession depends on his/her self-efficacy belief concerning that profession (Moe, Pazzaglia, \& Ronconi, 2010, p. 1145). All these statements indicate that self-efficacy belief is actually converted into the self-actualization of know-how belief (Tschannen-Moran \& Johnson, 2011, p. 751).

It is stated that those individuals whose self-efficacy is high set big targets, and strive to reach those targets. They tend to succeed by struggling in difficult situations, and continue striving even in the face of failure (Bandura, 1993, p. 144), that is, making decisions, setting a target, making an effort in a situation to the extent and how long they are affected by self-efficacy beliefs (Khorrami-Arani, 2001, p. 18). Perceived self-efficacy - which is a basic concept of social learning theory and meets the belief about ones' idea how to be successful while working - enables an individual to control every event and situation affecting his/her life, and gives strength to allow the individual to endure problems and any stress that he/she experiences (Bandura, 1994). When the studies concerning teacher self-efficacy which demonstrate a positive effect on academic processes such as teaching and learning performance (Lavelle, 2006, p. 75; Kelm \& McIntosh, 2012, p. 138; Bautista, 2011, p. 347; Şaşmaz-Ören, Ormanc1, \& Evrekli, 2011, p. 1691) are examined, it is seen that it affects variables such as achievement and motivation in school (Gorozidis \& Papaioannou, 2011, p. 235; Hartman, 2012, p. 729), directing interest (Bonitz, Larson, \& Armstrong, 2010, p. 225), affecting effective methods (Chong \& Kong, 2012, p. 267), cooperation with parents and decreasing negative situations (Viel-Ruma, Houchins, Jolivette, \& Benson, 2010, p. 226; Çalık, Sezgin, Kavgacı, \& Kılınç, 2012, p. 2499). This study aims to take into account the positive impact of teacher self-efficacy on teaching.

\subsection{The Importance of the Problem}

The aim of this research is to identify the interpersonal self-efficacy beliefs of German teacher trainers in Turkey in terms of the teaching process. It aims to analyze the German teacher trainers' views concerning self-efficacy in secondary education in terms of a variety of variables.

\section{Method}

This research takes the form of a descriptive survey model. A survey model includes a model which describes and explains the current situation by taking samples from a given population (Arseven, 1994; Balc1, 1995; Karasar, 2005).

\subsection{Population and Sample}

The population involved in the research consists of German teacher trainers who have given various seminars related to German language teaching after they attended a variety of in-service training seminars identified jointly by Goethe University and the Ministry of Education in Turkey. Moreover these more experienced and Turkish originated teacher trainers work in high schools as teachers of German language in the seven geographical regions of Turkey - the Mediterranean, the Black Sea, Marmara, Aegean, Central Anatolia, Eastern Anatolia and South-eastern Anatolia Regions - during the academic year 2012-2013.

\subsection{Sampling Procedures}

The sample comprises 52 German teacher trainers who were randomly chosen from the relevant population and who agreed to provide the necessary data. The distribution of the respondents who were involved in the study was based on the variables seen in Table 1. The research scale was completed by about 100 German teacher trainers in Turkey. The scale was carried out in the seminars which were held regularly, and the scale was sent to the teacher trainers through e-mail. The scale was administered to the teacher trainers through the special permission of the seminar authorities and also through these trainers' e-mails that taken from the authorized person. 
Table 1. The distribution of the respondents who were involved in the study based on selected variables.

\begin{tabular}{|c|c|c|c|c|c|c|c|}
\hline Variables & & $\mathbf{N}$ & $\%$ & Variables & & $\mathbf{N}$ & $\%$ \\
\hline \multirow{4}{*}{$\begin{array}{l}\text { Working } \\
\text { period } \\
\text { (year) }\end{array}$} & $6-10$ & 8 & 15.4 & \multirow{2}{*}{ Gender } & Female & 18 & 34.6 \\
\hline & $11-15$ & 12 & 23.1 & & Male & 34 & 65.4 \\
\hline & $16-20$ & 13 & 25,0 & \multirow{7}{*}{$\begin{array}{l}\text { Geographical } \\
\text { region }\end{array}$} & Mediterranean & 8 & 15.4 \\
\hline & $21+$ & 19 & 36.5 & & Black Sea & 9 & 17.3 \\
\hline \multirow{5}{*}{$\begin{array}{l}\text { School } \\
\text { Types in } \\
\text { terms of } \\
\text { Graduation } \\
\text { (Secondary } \\
\text { Education) }\end{array}$} & Science & 5 & 9.6 & & Marmara & 4 & 7.7 \\
\hline & $\begin{array}{l}\text { AnatoliaTeachers Training } \\
\text { High School }\end{array}$ & 15 & 28.8 & & Aegean & 8 & 15.4 \\
\hline & Anatolia High School & 11 & 21.2 & & Central Anatolia & 9 & 17.3 \\
\hline & $\begin{array}{l}\text { Anatolia Technical and } \\
\text { Vocational High School }\end{array}$ & 7 & 13.5 & & Eastern Anatolia & 9 & 17.3 \\
\hline & General High School & 14 & 26.9 & & $\begin{array}{l}\text { Southeastern } \\
\text { Anatolia }\end{array}$ & 5 & 9.6 \\
\hline
\end{tabular}

\subsection{Data Collection Tool}

Include The version of "The Teacher Interpersonal Self-efficacy Scale (TISE)" which was developed by Brouwers and Tomic in 2002 and translated into Turkish, was evaluated in terms of its reliability and validity by Çapri and Kan (2006). It was used to identify the interpersonal self-efficacy beliefs of German teacher trainers in Turkey who were teaching German in high schools. The scale consists of 18 Likert-type items. The scale has three factors. These are: "The perceived self-efficacy belief in classroom management", "The perceived self-efficacy belief concerning support from colleagues" and "The perceived self-efficacy belief concerning support from school administration". In terms of the Likert-type responses, the items are rated as "Strongly Disagree (1.00-1.80), Disagree (1.81-2.60), Neutral (2.61-3.40), Agree (3.41-4.20) and Strongly Agree (4.21-5.00)".

\subsection{Data Analysis}

In this study, the items in the Likert-type scale were analyzed in terms of arithmetic mean and standard deviation. While "t-test" in paired comparisons and ANOVA test in multiple comparisons were used in the analysis of changes in the German teacher trainers' views according to the variables, the Scheffe test was used to determine in which groups the differences occurred. In this study, only the significant items based on the variables concerning the teacher trainers' views were taken into account. The level of significance in the study was accepted as $\mathrm{p}=0.05$.

\section{Results}

\subsection{The Self-efficacy Levels of German Teacher Trainers in Turkey in Terms of Managing Their Students'Behaviour}

The German teacher trainers' views concerning their self-efficacy in terms of managing their students' behaviour in classes are seen in Table 2.

Table 2. The German teacher trainers' views concerning their self-efficacy in terms of managing their students' behaviour in class

\begin{tabular}{|c|c|c|c|}
\hline Item & Teachers' Views & $\overline{\mathrm{X}}$ & ss \\
\hline 7 & I can persuade problematic or maladaptive students to participate in lessons. & 4.19 & .88 \\
\hline 8 & I can cope with problematic or maladaptive students adequately. & 4.44 & .61 \\
\hline 9 & I can prevent problematic students from disturbing the whole class. & 4.08 & .92 \\
\hline 10 & I can re-motivate students when they are off-task in lessons. & 4.40 & .82 \\
\hline 11 & I can re-direct the student when he/she disturbs the lesson. & 4.10 & .87 \\
\hline 12 & I can reach even the most problematic students. & 3.98 & 1.21 \\
\hline 13 & I can manage the classroom quite well. & 4.17 & .65 \\
\hline 14 & There are few students whom I cannot cope with. & 4.06 & .87 \\
\hline
\end{tabular}

The item "I can persuade problematic or maladaptive students to participate in lessons" in Table 2, was answered as "agree" ( $\overline{\mathrm{X}}=4.19)$ by the German teacher trainers who were involved in the study. There is a significant difference 
among the teachers' views concerning the related item based on the gender variable $\left(\mathrm{t}_{(50)}=2.991 ; \mathrm{p}<0.05\right)$. It can be said that the male teacher trainers $(\overline{\mathrm{X}}=4.44)$ are more competent than the female teachers $(\overline{\mathrm{X}}=3.72)$ in persuading problematic or maladaptive students to participate in lessons. There is a significant difference in terms of the teachers' views concerning the related item based on the years of teaching experience variable $\left(\mathrm{KWH}_{7}=9.715 ; \mathrm{p}<0.05\right)$. The result of the MWU test shows that differences occurred between three and five groups $\left(\mathrm{MWU}_{3-5}=42.50 ; \mathrm{p}<0.05\right)$. According to this result, teachers with 21 year and over in terms of experience $\left(\mathrm{MR}_{5}=19.76\right)$ were seen to have more competence when it comes to persuading problematic or maladaptive students to participate in lessons than had the 11-15 year experienced teachers $\left(\mathrm{MR}_{3}=10.04\right)$.

The item "I can cope with problematic or maladaptive students adequately" in Table 2 was answered as "strongly agree" $(\overline{\mathrm{X}}=4.44)$ by the respondents. There is a significant difference among the teachers' views concerning this item based on the gender variable $\left(\mathrm{t}_{(50)}=3.091 ; \mathrm{p}<0.05\right)$. It can be seen that the male teacher trainers $(\overline{\mathrm{X}}=4.61)$ are more competent than the female teachers $(\overline{\mathrm{X}}=4.11)$ in addressing problematic or maladaptive students adequately. There is a significant difference among the teachers' views concerning this item based on the years of work experience variable $(\mathrm{F}=3.593$; $\mathrm{p}<0.05)$. The result of the Scheffe test shows that this difference occurred among the 11-15 year experienced teacher group and the 21 year and over experienced teachers group. According to this result, it was determined that the teacher trainers with 21 years and over of experience $\left(\bar{X}_{5}=4.63\right)$ had more competence when it comes to coping with problematic or maladaptive students adequately than did the 11-15 year experienced teacher trainer groups $\left(\overline{\mathrm{X}}_{1}=4.00\right)$.

The item "I can prevent the problematic students from disturbing the whole class" in Table 2 was answered as "agree" $(\overline{\mathrm{X}}=4.08)$ by the German teacher trainers. There is a significant difference among the teacher trainers' views concerning the related item based on the years of work experience variable $(F=3.673 ; \mathrm{p}<0.05)$. The results of the Scheffe test shows that this difference occurred among the 11-15 year experienced teacher group and the 21 year and over experienced teachers group. There is also a significant difference among the teacher trainers' views concerning the $10^{\text {th }}$ item which is not a parametric item based on the working period variable $\left(\mathrm{KWH}_{10}=11.509 ; \mathrm{p}<0.05\right)$. The difference was noted among the 6-10 year experienced teacher group and the 21 years and over experienced teachers group. According to this result, the latter group $\left(\mathrm{MR}_{5}=16.95\right)$ were seen to have more competence when it comes to re-motivating the students who are off-task in lessons compared with the 6-10 year experienced teachers group $\left(\mathrm{MR}_{2}=7,00\right)$. Similarly, there is a significant difference in terms of the teachers' views concerning the $10^{\text {th }}$ item in the same group based on the working period variable $\left(\mathrm{KWH}_{11}=16.856 ; \mathrm{p}<0.05\right)$. The difference was among the 6-10 year experienced teacher group and the 21 year and over experienced teachers group $\left(\mathrm{MWU}_{2-5}=16.50 ; \mathrm{p}<0.05\right)$. According to this result, the young teachers $\left(\mathrm{MR}_{2}=6.56\right)$, are seen to have less competence when it comes to re-directing student when the lesson is disturbed, compared with the more experienced teachers $\left(\mathrm{MR}_{5}=17.13\right)$. This case can be explained in the sense that those teachers who have greater work experience are experienced in this issue, while younger teachers have less competence. Besides, this item was answered as "agree" ( $\overline{\mathrm{X}}=4.10)$ by the German teacher trainers. Similarly, the item "I can reach even the most problematic students." was answered as "agree" $(\overline{\mathrm{X}}=3.98)$ by the teacher trainers.

The item which aims to ascertain the teachers' views concerning classroom management "I can manage the classroom quite well" was seen to be answered as "agree" $(\overline{\mathrm{X}}=4.17)$ by the participants. This finding indicates that the German teacher trainers generally have enough competence to manage classroom pedagogically. There is a significant difference concerning this item based on the gender variable $\left(\mathrm{t}_{(50)}=2.949, \mathrm{p}<0.05\right)$. However, the item "There are few students whom I cannot cope with" on the classroom management issue in the scale was answered as "agree" $(\overline{\mathrm{X}}=4.06)$ by the participants.

\subsection{The Self-efficacy Levels of German Teacher Trainers in Turkey in Terms of Obtaining Support from Administrators}

The German teacher trainers' views concerning their competence to obtain support from administrators are seen in Table 3.

Table 3. The German teacher trainers' views concerning their competence to obtain support from administrators

\begin{tabular}{llrc}
\hline Item & Teachers' Views & $\bar{X}$ & Ss \\
\hline $\mathbf{1 5}$ & I am confident about asking for school administrators' advice and suggestions & 4.19 & .79 \\
& when necessary. & & \\
$\mathbf{1 6}$ & I can obtain the support of school administrators when necessary. & 4.42 & .77 \\
$\mathbf{1 7}$ & I am confident about asking school administrators to help me when necessary. & 4.29 & .67 \\
$\mathbf{1 8}$ & I can easily talk to school administrators about problems in the workplace. & 4.58 & .64 \\
$\mathbf{1 9}$ & I can convey problems to school administrators when necessary. & 4.41 & .72 \\
\hline
\end{tabular}


The item "I am confident about asking for school administrators' advice and suggestions when necessary" in Table 3 was answered as "agree" ( $\overline{\mathrm{X}}=4.19)$ by the German teacher trainers. A significant difference among the teachers" views concerning this item based on the working period variable $(\mathrm{F}=8.468 ; \mathrm{p}<0.05)$ was seen. The result of the Scheffe test showed that a difference existed among the 6-10 and 11-15 year experienced teacher groups, and among the 16-20 and 21 year and over experienced teachers groups. This finding suggests that the teacher trainers with 16-20 year's experience $\left(\overline{\mathrm{X}}_{4}=4.69\right)$, think more positively in terms of being confident to ask school administrators for advice and suggestions when necessary, compared with the 6-10,11-15 and 21 years and over experienced teacher trainers $(\bar{X}$ ${ }_{2}=3.25, \overline{\mathrm{X}}_{3}=4.42, \overline{\mathrm{X}}_{5}=4.10$ ). The item "I can obtain the support of school administrators when necessary" in Table 3 was answered as "completely agree" $(\overline{\mathrm{X}}=4.42)$ by the teacher trainers. This case shows that the teacher trainers are competent when it comes to getting support from school administrators at a good level. There is a significant difference with regard to the teachers' views concerning the $17^{\text {th }}$ item which is not a parametric item, based on the length of experience variable $\left(\mathrm{KWH}_{17}=11.585 ; \mathrm{p}<0.05\right)$. The $\mathrm{MWU}_{17}\left(\mathrm{MWU}_{2-3}=17.500 ; \mathrm{p}<0.05\right)$ test indicates that the difference was between the 6-10 years of experience teacher group and the 21 year and over years of experience teacher group. Similarly, the significant difference among the teachers' views concerning the $19^{\text {th }}$ item which is not a parametric item $\left(\mathrm{KWH}_{19}=10.963 ; \mathrm{p}<0.05\right)$ is between the 16-21 year's experience teacher group and 21 year and over year's experience teacher group $\left(\mathrm{MWU}_{4-5}=62.50 ; \mathrm{p}<0.05\right)$. According to this result, the latter group $\left(\mathrm{MR}_{5}=19.71\right)$ have more competence than the 16-20 year's experience teacher group $\left(\mathrm{MR}_{4}=11.81\right)$. In addition, the $18^{\text {th }}$ item was answered as "completely agree" ( $\overline{\mathrm{X}}=4.58)$, demonstrating that the teacher trainers in general feel free to talk to school administrators about any problem.

\subsection{The Self-efficacy Levels of German Teacher Trainers in Turkey to Obtain Support from Their Colleagues}

The German teacher trainers' views concerning their competence to obtain support from their colleagues are seen in Table 4.

Table 4. The German teacher trainers' views concerning their competence to obtain support from their colleagues

\begin{tabular}{llrr}
\hline Item & Teachers' Views & $\bar{X}$ & ss \\
\hline $\mathbf{2 0}$ & I can ask for help from my colleagues about any issue when necessary. & 4.50 & .67 \\
$\mathbf{2 1}$ & I am confident about talking to my colleagues about problems in the work place. & 4.25 & .65 \\
$\mathbf{2 2}$ & I can ask for help from my colleagues when I come across a problem. & 4.57 & .63 \\
$\mathbf{2 3}$ & I feel free to ask for my colleagues' advice when necessary. & 4.31 & .61 \\
$\mathbf{2 4}$ & I can always find a colleague to whom I can talk about problems in the work place. & 4.11 & .65 \\
\hline
\end{tabular}

The item "I can ask for help from my colleagues about any issue when necessary" in Table 4 was answered as "completely agree" $(\overline{\mathrm{X}}=4,50)$ by the German teacher trainers. This was not a parametric item and there was a significant difference on the part of the teacher trainers' views based on the gender variable $\left(\mathrm{MWU}_{20}=164.00 ; \mathrm{p}<0.05\right)$. This indicates that the male teacher trainers $\left(\mathrm{MR}_{2}=34.39\right)$ are more capable and confident when it comes to asking for help from their colleagues when necessary compared with the female teacher trainers $\left(\mathrm{MR}_{1}=22.32\right)$.

The item "I am confident about talking to my colleagues about problems in the work place" in Table 4 was answered as "completely agree" $(\overline{\mathrm{X}}=4.25)$ by the participants. There is a significant difference in terms of the teacher trainers' views concerning this item based on the working period variable $(\mathrm{F}=5.766 ; \mathrm{p}<0.05)$. The result of the Scheffe test showed that this difference existed among the 11-15 year experienced teacher group, the 16-20 year experienced teacher group, and the 21 year and over experienced teachers group. In addition, the item "I can ask for help from my colleagues when I come across a problem" was answered as "completely agree" $(\overline{\mathrm{X}}=4.57)$ by the German teacher trainers. In this regard, it is understood that these teachers are in agreement with each other when it comes to asking for help from their colleagues when they come across a problem. It was seen that there was a significant difference among the teacher trainers' views concerning this item based on the gender variable $\left(\mathrm{MWU}_{20}=192.00 ; \mathrm{p}<0.05\right)$ and this difference was in favour of the male teacher trainers $\left(\mathrm{MR}_{1}=23.15 ; \mathrm{MR}_{2}=32.83\right)$.

The teacher trainers answered the 19th item in the scale as "completely agree" $(\overline{\mathrm{X}}=4.31)$. There is a significant difference among the teacher trainers' views concerning this item which is not a parametric item, based on the working period variable $\left(\mathrm{KWH}_{23}=11.759 ; \mathrm{p}<0.05\right)$. The $\mathrm{MWU}_{23}\left(\mathrm{MWU}_{4-5}=51.50 ; \mathrm{p}<0.05\right)$ test indicated that this difference existed among the 16-20 year experienced teacher group and the 21 year and over experienced teacher group. Similarly, there is a significant difference between the 11-15 years experience teacher group and the 21 year and over experienced teacher group with regard to the same item $\left(\mathrm{MWU}_{3-5}=59.00 ; \mathrm{p}<0.05\right)$. Based on this result, the 21 year and over experienced teachers $\left(\mathrm{MR}_{5}=18.89\right)$ adopted the item more, compared with the 16-20 year experienced teachers 
$\left(\mathrm{MR}_{3}=15.42\right)$.

The last item of the scale "I can always find a colleague to whom I can talk about problems in the work place" was answered as "agree" $(\overline{\mathrm{X}}=4.11)$. There is a significant difference in terms of the teacher trainers" views concerning this item based on the working period variable $(\mathrm{F}=3.975 ; \mathrm{p}<0.05)$. This difference was seen to exist between the 16-20 year's experience teacher group and the 21 year and over experience teachers group using the Scheffe test. The difference $\left(\overline{\mathrm{X}}_{4}=3.69, \overline{\mathrm{X}}_{5}=4.42\right)$ was seen to be in favour of the 21 year and over experienced teachers groups. This case stressed out that the 21 years and over experience teachers group who have more competence when it comes to finding a colleague to whom they can talk about the problems in the work place, compared with the teachers with 16-20 year's experience.

\section{Discussion}

The aim of this study is to determine the interpersonal self-efficacy beliefs of German teacher trainers in Turkey. In this context, the teacher trainers, who are responsible for teaching German in secondary education, demonstrated views including the perceived self-efficacy belief in classroom management, the perceived self-efficacy belief concerning support obtained from colleagues and the perceived self-efficacy belief concerning support obtained from administrators were analyzed descriptively, based on years of work experience and gender variables.

In the analysis of the German teacher trainers' views concerning the competency to manage their students' behaviour in the classroom, there is a significant difference among the teacher trainers' views in encouraging maladaptive students to participate in lessons and in being able to address them in terms of the gender variable. It was understood that the male teacher trainers' interpersonal self-efficacy beliefs were higher than those of their female counterparts in terms of encouraging problematic or maladaptive students to participate in lessons and addressing them adequately. This situation can be understood as male teachers displaying more authoritative behaviour. At this point, it can be deduced that teachers' self-efficacy levels affect their social behaviours. That is, it can affect how they treat their students. Bandura (1982: 143), in this context, stresses that the level of self-efficacy being high means being good at a social level as well.

There is a significant difference among teachers' views concerning the same issues in terms of the working period variable, and it was seen that the differences were in favour of the more experienced teachers. With regard to this point, it is understood that teachers' experiences they have acquired over the years indicated positive effects when it comes to involving students in lessons actively, and addressing their students' levels of motivation positively. In addition, it was seen that the more experienced teachers were more successful in preventing problematic students from disturbing the whole class compared with less experienced teachers. It can be thought that the extent of teachers' experience is effective when it comes to dealing with especially problematic students. Besides, this result can be interpreted as the more experienced teachers having more self-efficacy when it comes to managing their students, thereby ensuring more order and cooperation in the classroom. The fact that teachers are confident and competent in a subject is expected to provide better and more effective results in terms of the teaching process. For that reason, teachers' self-efficacy levels have to be high. A study carried out in this context underlines the fact that teacher self-efficacy is so important, indicating a direct relationship between teachers' self- efficacy levels and their satisfaction with their profession (Viel-Ruma et al., 2010, p. 231).

It was identified that there is a significant difference between teachers' views concerning re-motivating and re-directing those students who are off-task or who are interfering with the lesson, based on the working period variable. This difference is in favour of more experienced teachers, and it can be said that young teachers have less competency concerning re-motivating and re-directing students. Classroom management was examined as a sub-title of the management of student behaviour. It was understood that the German teacher trainers are pedagogically competent when it comes to managing the classroom as a whole. However, there was a significant difference in favour of male teachers in the related item based on the gender variable.

In the analysis of the teacher trainers' views concerning the competency to obtain support from administrators, it was seen that the more experienced teachers were more confident with regard to consulting with school administrators in the event of a problem and asking for help at this point as a whole. This can be interpreted as more experienced teachers having a good relationship with school administrators and feeling free to get help from them. On the other hand, it may be the case that more experienced teachers have more self-efficacy when it comes get social support in the school. In this regard, it is mentioned in the study by Chong $(2012$, p. 281) that teachers acting on a subject collaboratively and exchanging ideas can increase teacher self-efficacy. So, it can be thought that teachers' trying to solve problems by obtaining support from administrators as part of a collaborative spirit, can make them active in this process and can strengthen their social self-efficacy beliefs. Ross and Gray (2006, p. 812) and Çalık et al. (2012, p. 2501) examine the relationship between administrative behaviour and teacher self-efficacy in their studies and conclude that there is a 
positive and significant difference between school administrators' behaviour with regard to the teaching process and teachers' self-efficacy. They stress that administrators' behaviour patterns enable teachers to be able to behave confidently and affect their self-efficacy when it comes to seeking support in the event of a problem.

In the analysis of the German teacher trainers' views concerning the competency to obtain support from colleagues, it was seen that there was a significant difference in favour of the male teachers concerning talking about problems at school and solving them. In this context, it can be said that male teachers are more confident when it comes to expressing problems, and in seeking collaboration and cooperation. In addition, it was especially the case that more experienced teachers felt free to seek advice and suggestions from their colleagues, and could find a colleague to whom they could talk about problems. It can be said that more experienced teachers are more competent with regard to talking about school problems, and in cooperating and exchanging ideas with colleagues. In this context, Wei, Russell and Zakalik (2005, p. 602) support the idea that teachers' self-efficacy in a social sense makes them more effective in the teaching process, by stating that interpersonal self-efficacy can be increased, which decreases feelings of loneliness. Some of the results of the studies carried out in this context show that teachers' interpersonal self-efficacy with regard to their students, colleagues and administrators, can contribute to making teachers more constructive and effective in education, and to removing the problems or inconveniences they may face in an educational context (Anderson \& Betz, 2001; Çapri \& Kan, 2006). Other studies dealing with the various variables which affect teachers' self-efficacy in particular are required (Kelm \& McIntosh, 2012).

The research has emphasized that teachers' beliefs concerning their competence when it comes to managing their students' behaviour and getting support from their administrators and colleagues varied in terms of the years of work experience and gender. According to these results, it is understood that more experienced male teachers are in good communication with their students, colleagues and administrators, and more confident when it comes to sharing problems and exchanging their ideas. That is, their interpersonal self-efficacy beliefs were deduced to be at a higher level. In this context, it is possible to obtain important data concerning teachers' self-efficacy beliefs through studies dealing with such beliefs. In particular, education programs can be reorganized by taking into account the regulations aimed at ensuring and developing teachers' self-efficacy. These studies are thought to have made a crucial contribution to the teaching profession, sustaining teaching, and increasing teachers' competences in terms of the teaching process.

\section{References}

American Psychological Association. (1972). Ethical standards of psychologists. Washington, DC: American Psychological Association.

Anderson, C. A., Gentile, D. A., \& Buckley, K. E. (2007). Violent video game effects on children and adolescents: Theory, research and public policy. http://dx.doi.org/10.1093/acprof:oso/9780195309836.001.0001

Anderson, S. L., \& Betz, N. E. (2001). Sources of social self-efficacy expectations: their measurement and relation to career development. Journal of Vocational Behaviour, 58(1), 98-117.

Arseven, A. D. (1994). Alan araştırma yöntemi-ilkeler, teknikler, örnekler. [Areas of research methods-principles, techniques, samples]. Tekış1k Printing Press: Ankara.

Balc1, A. (1995). Sosyal bilimlerde araştırma. [Research in social sciences]. Publication of Ankara University Education Sciences Faculty: Ankara.

Bandura, A. (1977). Self-efficacy: toward a unifying theory of behavioural change. Psychological Review, 84(2), 191-215.

Bandura, A. (1982). Self-efficacy mechanism in human agency. American Psychologist, 37(2), 122-147.

Bandura, A. (1993). Perceived self-efficacy in cognitive development and functioning. Educational Psychologist, 28(2), 117-148.

Bandura, A. (1994). Self-efficacy. In V. S. Ramachaudran (Ed.), Encyclopedia of human behaviour, 4, 71-81. New York: Academic Press. (Reprinted in H. Friedman [Ed.], Encyclopedia of mental health. San Diego, Academic Press, 1998.

Bandura, A., \& Locke, E. A. (2003). Negative self-efficacy and goal effects revisited. Journal of Applied Psychology, 88(1), 87-99.

Bautist, N. U. (2011). Investigating the use of vicarious and mastery experiences in influencing early childhood education majors' self-efficacy beliefs. Journal of Science Teacher Education, 22, 333-349. http://dx.doi.org/10.1007/s10972-011-9232-5.

Bonitz, V. S., Larson, L. M., \& Armstrong, P. I. (2010). Interests, self-efficacy, and choice goals: An experimental 
manipulation. Journal of Vocational Behavior, 76, 223-233.

Chan, D. W. (2008). General, collective, and domain-specific teacher self-efficacy among Chinese prospective and in-service teachers in Hong Kong. Teaching and Teacher Education, 24, 1057-1069. http://dx.doi.org/10.1016/j.tate.2007.11.010.

Cho, Y., \& Shim, S. S. (2013). Predicting teachers' achievement goals for teaching: The role of perceived school goal structure and teachers' sense of efficacy. Teaching and Teacher Education, 32, 12-21.

Chong, W. H. (2012). Teacher collaborative learning and teacher self-efficacy: the case of lesson study. The Journal of Experimental Education, 80(3), 263-283. http://dx.doi.org/10.1080/00220973.2011.596854.

Chong, W. H., \& Kong, C. A. (2012). Teacher collaborative learning and teacher self-efficacy: the case of lesson study. The Journal of Experimental Education, 80(3), 263-283. http://dx.doi.org/10.1080/00220973.2011.596854.

Çalık, T., Sezgin, F., Kavgacı, H., \& Kılınç, A. Ç. (2012). Examination of relationships between instructional leadership of school principals and self-efficacy of teachers and collective teacher efficacy. Educational Sciences: Theory \& Practice, 12(4), 2498-2504.

Çapri, B., \& Kan, A. (2006). Öğretmen kişilerarası öz-yeterlik ölçeğinin türkçe formunun geçerlik ve güvenirlik çalışması. [The teacher interpersonal self-efficacy scale: validity and reliability study of Turkish form]. Mersin University Journal of Faculty of Education, 2(1), 48-61.

Evers, W. J. G., Brouwers, A., \& Tomic, W. (2002). Burnout and self-efficacy: A study on teachers' beliefs when implementing an innovative educational system in the Netherlands. British Journal of Educational Psychology, 72, 227-243.

Friedman, I. A., \& Kass, E. (2002). Teacher self-efficacy: a classroom-organization. Conceptualization. Teaching and Teacher Education, 18, 675-686.

Gorozidis, G., \& Papaioannou, A. (2011). Teachers' self-efficacy, achievement goals, attitudes and intentions to implement the new Greek physical education curriculum. European Physical Education Review, 17(2), 231-253. http://dx.doi.org/10.1177/1356336X11413654.

Guo, Y., Justice, L. M., Sawyer, B., \& Tompkins, V. (2011). Exploring factors related to preschool teachers' self-efficacy. Teaching and Teacher Education, 27, 961-968. http://dx.doi.org/10.1016/j.tate.2011.03.008.

Guo, Y., Piasta, S. B., Justice, L. M., \& Kaderavek, J. N. (2010). Relations among preschool teachers' self-efficacy, classroom quality and children's language and literacy gains. Teaching and Teacher Education, 26, 1094-1103. http://dx.doi.org/10.1016/j.tate.2009.11.005.

Hartman, E. (2012). A scale to measure teachers' self-efficacy in deaf-blindness education. Journal of Visual Impairment \& Blindness, December 2012, AFB.

Hoy, A. W., \& Spero, R. B. (2005). Changes in teacher efficacy during the early years of teaching: Acomparison of four measures. Teaching and Teacher Education 21, 343-356. http://dx.doi.org/10.1016/j.tate.2005.01.007.

Karasar, N. (2005). Bilimsel Araştırma Yöntemi. Nobel Yayınları: Ankara.

Kelm, J. I., \& McIntosh, K. (2012). Effects of school-wide positive behavior support on teacher self-efficacy. Psychology in the Schools, 49(2), 137-147. http://dx.doi.org/10.1002/pits.20624.

Khorrami-Arani, O. (2001). Researching computer self-efficacy. International Education Journal, 2(4), 17-24.

Kim, Y. H., \& Kim, Y. E. (2010). Korean early childhood educators' multi-dimensional teacher self-efficacy and ECE center climate and depression severity in teachers as contributing factors. Teaching and Teacher Education, 26, 1117-1123. http://dx.doi.org/10.1016/j.tate.2009.06.009.

Klassen, R. M., \& Chiu, M. M. (2011). The occupational commitment and intention to quit of practicing and pre-service teachers: Influence of self-efficacy, job stress, and teaching context. Contemporary Educational Psychology, 36, 114-129. http://dx.doi.org/10.1016/j.cedpsych.2011.01.002.

Lavelle, E. (2006). Techers' self efficacy for writing. Electronic Journal of Research in Educational Psychology, 8(4), 73-84.

Lee, B., Cawthon, S., \& Dawson, K. (2013). Elementary and secondary teacher self-efficacy for teaching and pedagogical conceptual change in a drama-based professional development. Teaching and Teacher Education, 30, 84-98.

Liaw, E. C. (2009). Teacher efficacy of pre-service teachers in Taiwan: The influence of classroom teaching and group 
discussions. Teaching and Teacher Education, 25, 176-180. http://dx.doi.org/10.1016/j.tate.2008.08.005.

Milner, R. H., \& Hoy, A. W. (2003). A case study of an African American teacher's self-efficacy, stereotype threat, and persistence. Teaching and Teacher Education, 19, 263-276. http://dx.doi.org/10.1016/S0742-051X(02)00099-9.

Moe, A., Pazzaglia, F., \& Ronconi, L. (2010). When being able is not enough. The combined value of positive affect and self-efficacy for job satisfaction in teaching. Teaching and Teacher Education, 26,1145-1153. http://dx.doi.org/10.1016/j.tate.2010.02.010.

Paraskeva, F., Bouta, H., \& Papagianni, A. (2008). Individual characteristics and computer self-efficacy in secondary education teachers to integrate technology in educational practice. Computers \& Education, 50, 1084-1091.

Ross, J. A., \& Gray, P. (2006). School leadership and student achievement: the mediating effects of teacher beliefs. Canadian Journal of Education 29, 3(2006), 798 - 822.

Savran Gencer, A., \& Çakıroğlu, J. (2007). Turkish preservice science teachers' efficacy beliefs regarding science teaching and their beliefs about classroom management. Teaching and Teacher Education, 23, 664-675. http://dx.doi.org/10.1016/j.tate.2005.09.013.

Şaşmaz Ören, F., Ormanc1, Ü., \& Evrekli, E. (2011). The Science and technology pre-service teachers' self-efficacy levels and opinions about alternative assessment and evaluation approaches. Educational Sciences: Theory \& Practice, 11(3), 1690-1698.

Tsahannen-Moran, M., \& Johnson, D. (2011). Exploring literacy teachers' self-efficacy beliefs: Potential sources at play. Teaching and Teacher Education, 27, 751-761. http://dx.doi.org/10.1016/j.tate.2010.12.005.

Viel Ruma, K., Houchins, D., Jolivette, K., \& Benson, G. (2010). Efficacy beliefs of special educators: the relationships among collective efficacy, teacher self-efficacy, and job satisfaction. Teacher Education and Special Education, 33(3), 225-233.

Wei, M., Russell, D. W., \& Zakalik, R. A. (2005). Adult attachment, social self-efficacy, self-disclosure, loneliness, and subsequent depression for freshman college students: a longitudinal study. Journal of Counseling Psychology, 52(4), 602-614.

\section{(cc) EY}

This work is licensed under a Creative Commons Attribution 3.0 License. 